\title{
UK の投与量と血中濃度の関係についで
}

\author{
松尾 理** 美 原 恒** 六島 喜 一***
}

Key words : Urokinase, thrombolysis, kinetics, Urokinase concentration,

序論

UK の投与に関していわゆる少量から大量ま で大きく分れており，まだ議論の多いところで ある. しかし，その議論の多くは UK の投与 量全体の大小を問題にしすぎたきらいがあり, UK 投与に伴う血中 UK 濃度の高低について はほとんぞ論じられていない1). UK 投与によ り血栓溶解を目指した際, 血中 UK 濃度は血 栓を溶解せしめる重要な因子となってくる．そ こで，血中 UK 濃度が UK の投与量とどうい う関数関係にあるかを理論的に求め, 得られた 理論式を実験結果と対応させ比較検討した.

\section{I. 材料および方法}

家鬼：正常家鬼（体重2. $5 \mathrm{~kg} \sim 3.0 \mathrm{~kg}$ ）を使用 した。

UK：Uronase（持田製薬社製 Urokinase）を 生食水に溶解して使用した.

フィブリン平板 : 標準および加熱平板を用い た.

\section{A. 理論的方法}

\section{1. 血中 $\mathbf{U K}$ 濃度}

投与された UK が生体内で拡散分布できる space を血漿内の みと限定し, one compartment model として plateau principle を適用 した ${ }^{122)}$.すなわち，UK の毎分投与量を $\mathrm{A}$ (unit $/ \mathrm{min}$ ), 血漿中の $\mathrm{UK}$ 濃度を $\mathrm{C}$ (unit $/ \mathrm{m} l$ ), 血漿量を $\mathrm{V}(\mathrm{m} l)$, 血漿中に存在する全 UK 量
A : administered UK per min

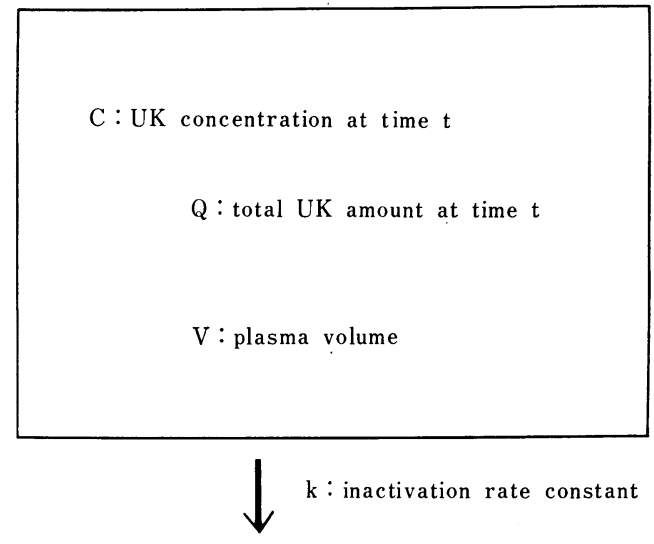

Fig. 1 Schema for the one compartment model of UK in the circulatory blood.

を $\mathrm{Q}$ (unit) とし，さらに，血漿へ投与された $\mathrm{UK}$ の活性が失われていく速度定数を $\mathrm{k}\left(\mathrm{min}^{-1}\right)$ とする (図 1). この UK の生理学的意味は, UK が血漿中で antiplasmin などによって失活 していく fraction と, UK が代謝されて血漿 中から消失していく fraction の両方を含んでい るものとする。

まず，血漿中に存在する UK の量・濃度関 係から

$$
\mathrm{Q}=\mathrm{C} \cdot \mathrm{V} \quad \cdots \cdot \cdot(1)
$$

が成立する．また血漿中の UK 量の変化は

$$
\frac{\mathrm{dQ}}{\mathrm{dt}}=-\underline{\mathrm{k}} \cdot \mathrm{Q}+\mathrm{A}
$$

で表わせる．乙の(1)(2)式から C について解く

* Relation between UK concentration in plasma and administered dosage of UK. (The 4th Congress of the Japanese Society on Thrombosis and Hemostasis, Nov. 30, 1975).

** 宮崎医科大学第二生理学〔 〔 $789-16$ 宮崎県宮崎郡清武町木原5200〕, Osamu MATSUO, Hisashi MIHARA : Department of Physiology, Miyazaki Medical College, Miyazaki, Japan.

*** 神戸大学医学部第一生理学, Yoshikazu ROKUSHIMA : Department of Physiology, Kobe University School of Medicine, Hyogo, Japan. 


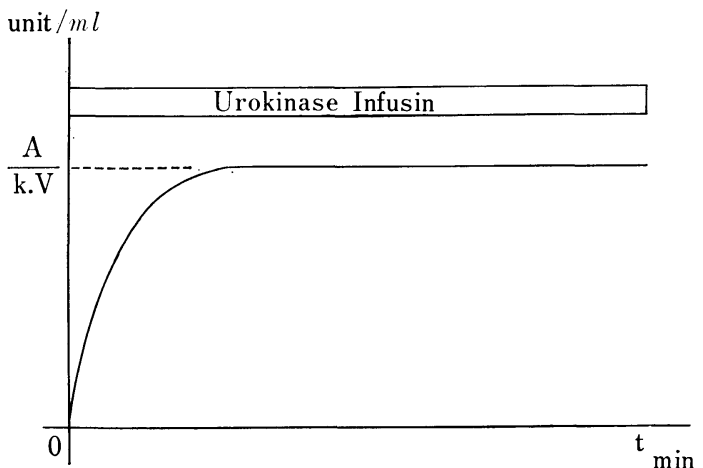

Fig. 2 UK concentration in the plasma, showing the attainment of the plateau value.

Ordinate, plasma UK concentration; abscissa, time after commencement of UK infusion.

と,

$$
\mathrm{C}=\frac{\mathrm{A}}{\underline{\mathrm{k}} \cdot \mathrm{V}}\left(1-\mathrm{e}^{-\underline{\mathrm{k}} \mathrm{t}}\right)
$$

となる。

この式が示す血中 UK 濃度の時間経過は,

図 2 で示されたように，UK 投与開始と共に上 昇し，ある時間たつと一定の值に落ち着き，以 後そのプラトーの值を示し続ける.とのプラト 一の值は(3)式加わ加るように $\mathrm{A} / \underline{\mathrm{k}} \cdot \mathrm{V}$ になる. この $\mathrm{A}, \underline{\mathrm{k}}, \mathrm{V}$ の内 $\mathrm{k}, \mathrm{V}$ はほぼ定数とみなせ るので，血中 UK 濃度は毎分投与量に比例関 係にあるといえる.すなわち，毎分投与量が大 きければ大きいほど，血中 UK 濃度は高くな り，逆に毎分投与量が小さければ小さいほど血 中 UK 濃度は低くなる。

\section{2. プラトー時間}

図2で示されたような血中 UK 濃度の時間 経過から，血中 UK 濃度がプラトーに達する までの時間を求めてみた。 血中 UK 濃度がプ ラトーの值 $(\mathrm{A} / \underline{\mathrm{k}} \cdot \mathrm{V})$ の $98 \%$ になった時にプラ トーに達したとすると，

$$
\mathrm{C}=0.98 \times \mathrm{A} / \underline{\mathrm{k}} \cdot \mathrm{V} \quad \cdots \cdots(4)
$$

(3)と(4)とから t について解くと

$$
\mathrm{t}=-\frac{\ln 0.02}{\underline{\mathrm{k}}}
$$

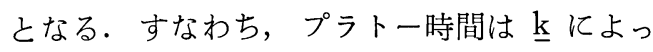
て決る定数である.

(3) UK 活性消失速度定数
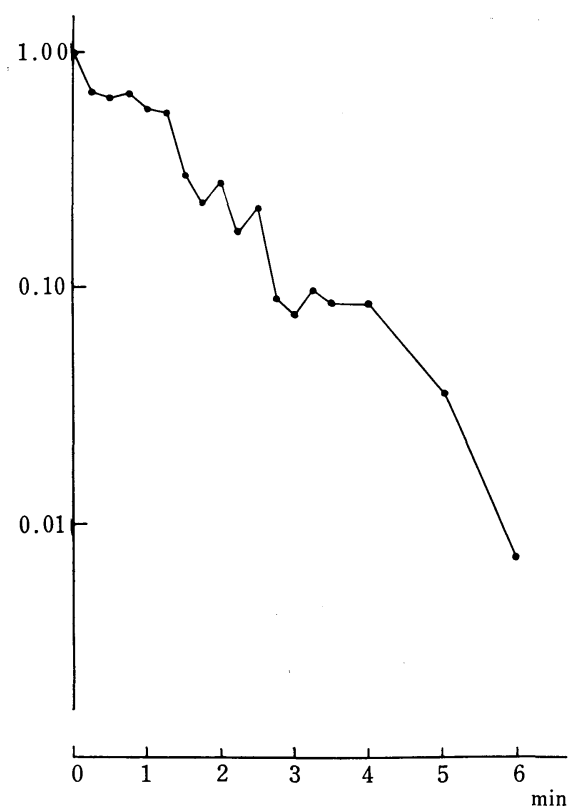

Fig. 3 Decay in plasma fibrinolytic activity after single shot injection of UK. Ordinate, fibrinolytic activity; abscissa, time after UK injection.

one-shot で投与された UK の活性が指数関 数的に減衰するとすれば

$$
\mathrm{Q}=\mathrm{Q}_{0} \cdot \mathrm{e}^{-\mathrm{k} t}
$$

という式が成立する， $Q_{0}$ を時間 0 における血 漿中に存在する UK 量とする. (6)式は

$$
\ln \left(\mathrm{Q} / \mathrm{Q}_{0}\right)=-\underline{\mathrm{kt}} \quad \cdots \cdots(7)
$$

となる.したがって, one-shot で投与した時の UK 活性の減衰経過を片対数上に plot するこ とにより $\mathrm{k}$ を計算できる.

\section{II. 結 果}

\section{UK 活性消失速度定数の測定}

家兔に UK 20,000 単位を one-shot で投与 し, 以後経時的に採血し, 標準平板法で血中線 溶活性を測定した。溶解面積を単位換算し, 片 対数上に plot し，活性減衰曲線を代表できる 直線を外插し，時間 0 に打ける活性を求め，そ れを1.00として表示したのが図 3 である. 加熱 平板上で得られたプラスミン活性は非常に小さ く標準平板上の活性減衰曲線の解析に影響をお よぼさなかった．図 3 のグラフから（7)式によ り，俞は0.7となった。 


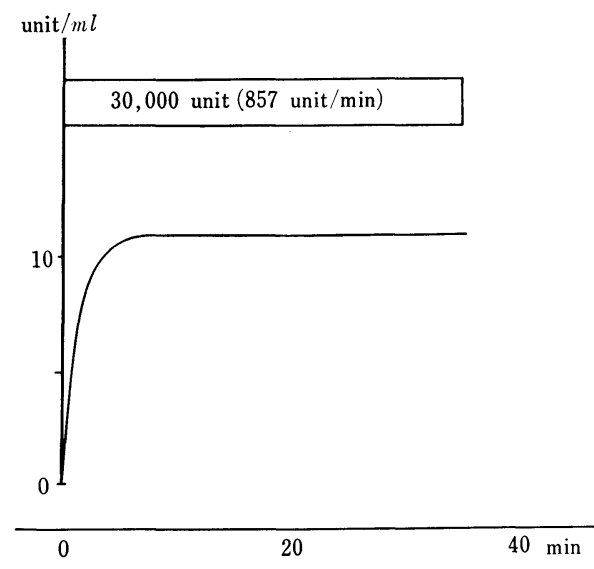

Fig. 4 Estimated plasma UK concentration after 30,000 units UK administration for $35 \mathrm{~min}$. Calculated plasma $\mathrm{UK}$ concentration was $11.1 \mathrm{unit} / \mathrm{ml}$. Ordinate, plasma UK concentration ; abscissa, time course after UK infusion.

\section{2. 血中 $\mathrm{UK}$ 濃度の予測}

1.により $\mathrm{k}$ が0.7と決まったので式(3)の時間 経過は, 図示するととができる.プラト一の值 は $\mathrm{A} / 0.7 \times \mathrm{V}$ となり，また，プラト一の時間は (5)式により 5.6 分となった。

\section{UK 30,000単位を35分で投与した場合の 血中 UK 濃度の予測之実験結果の比較}

UK 3 万単位を 35 分で投与すると毎分投与量 は 857 単位となり，家兔の血漿量を $110 \mathrm{~m} l$ とす れば，(3)式にょり予測血中 UK 濃度は11.1単 位となる (図 4 ). 血中 UK 濃度がこの予測通 りになるかどうかを検討した。 UK 投与開始後 経時的に採血し，血中線溶活性をフィブリン平 板上で測定した。図 5 に示したように血漿中に 屯 euglobulin 分画中にあ, 線溶活性は全くみ られなかった。

4. UK 40,000 単位を 11.5 分で投与した場 合，毎分投与量は 3,478 単位となり，家鬼の血 漿を $99 \mathrm{~m} l$ とすれば，(3)式により予測血中 UK 濃度は 50.2 単位となる. 実際に投与した結果, 血中線溶活性は投与開始後 7 分まで全くみられ なかった. 8 分目にようやく活性が出現し始 め, 以後急速に上昇し続け, 投与終了時で最大 活性を示した.この最大活性は unit 換算して 38単位であった. UK 投与中には，予測された

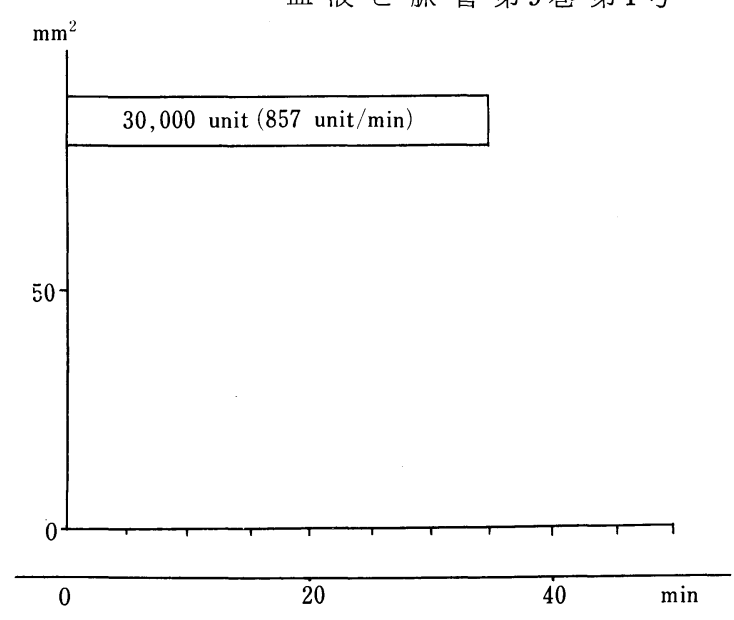

Fig. 5 Fibrinolytic activity after 30,000 units UK administration for $35 \mathrm{~min}$. No assayable activity in plasma and euglobulin fraction was detected. Ordinate, fibrinolytic activity in $\mathrm{mm}^{2}$; abscissa, time after starting $\mathrm{UK}$ administration.

血中 UK 濃度のプラトーはみられなかった。

\section{III. 考按}

$\mathrm{UK}$ 投与後の血中 UK 濃度は, 生体内で UK が拡散・分布できる space を血漿内のみと限定 するととにより, one compartment model と して plateau 法則を適応して計算可能になる. すなわち，血中 UK 濃度は，UK の毎分投与 量, 血漿量, おちよび UK 活性消失速度定数の 三者によって決められる．とのうち，血漿量と UK 活性消失速度定数はほぼ定数とみなせるの で，結局毎分投与量によって決められることに なる。乙れらの計算は，UK 投与後の生体の反 応を簡略・単純化しすぎている危険性を内蔵し ているが，この操作により一応 UK 投与後の 血中 UK 濃度が予測可能になった。したがっ て, UK 投与量の大小の問題は, 投与時間加ら 毎分投与量を計算し，得られる血中 UK 濃度 の高低を考慮して吟味しなければならない。

UK 活性消失速度定数 $\mathrm{k}$ を算出するため, UK を one-shot で投与し，その後にみられる 線溶活性の減衰過程を解析した。 その結果は図 3 のごとく，減衰率はかなり大きいととが判明 し，したがって $\mathrm{k}$ あ大きくなった．乙の成績 は Isotope を用いた成績3)4) でみられる fast 
phase での減衰率と対比されるが Isotope によ る解析はいずれも線溶活性を同時に測定してい ない. UK 投与後のゲル沪過により, UK の放 射活性は直ちに大分子部分と小分子部分に分加 れており ${ }^{5)}$ ， 線溶活性がかなり早く失われるこ とを示唆している. 一方 UK 投与後の血中 UK 濃度の予測值が実験結果とかなり違っていたて とにより，one-shot 投与実験で得られた $\mathrm{k} の$ 值がまだ小さすぎると考えられる．すなわち， UK 30,000単位を35分で投与した場合, 予測血 中 UK 濃度が 11.1 単位であったが，実測では 線溶活性は全くみられなかった(図 5 ). この実 験に用いた家兔の血漿 $1 \mathrm{~m} l$ は UK 25 単位を失 活させたので, 血漿全量で計 2,750 単位の UK が失活させられたととになる. 毎分投与量が 857単位なので3.2分後には antiplasmin 活性は なくなったと考えられる. Antiplasmin 活性が なくなれば血中に存在するUKは測定系の感度 の許すかぎり，測定可能なはずである.しか し，UK 投与の全時間を通じて線溶活性は全く 測定されなかった．次に UK 40,000 単位を 11. 5分で投与した場合, 線溶活性の出現は大変 遅く, また UK 投与中に線溶活性のプラト一 はみられなかった。との実験に用いた家鬼の血 漿 $1 \mathrm{~m} l$ で30単位の UK 活性を失活させるので 血漿全量で計 2,970 単位が失活させられたとと になる. この場合毎分投与量が 3,478 単位なの で 1 分以内に血漿中の antiplasmin 活性はなく なったと考えられるが，線溶活性の出現は UK 投与開始後 8 分目であり，乙の時点までに計 27,824 単位の UK が投与されている.

以上のととは, antiplasmin の活性が in vitro で測定した場合よりも，最む強く，かつ持続的 である事を示唆しており，したがって，ㅆ は実 測値よりあ大きいと思われるが，今後さらに検 討を要する問題である.

\section{要 約}

UK 投与後の血中 UK 濃度を求めるため, UK の拡散, 分布できる space を血漿をのみと 限定し, one compartment model として plateau principle を適用した。 その結果，血中 UK 濃度は主として UK の毎分投与量に依存
するととが明らかになった。 UK 活性消失速度 定数は, 家兔に UK を one-shot で投与し, 活性 減衰曲線を解析するととにより約 $0.7\left(\mathrm{~min}^{-1}\right)$ となった。とれらに基づき，血中 UK 濃度の 時間的経緯が予測でき, 実験的に得られた結果 と比較検討した.

UK 30,000単位を35分で投与した場合，毎分 投与量 857 単位家鬼の血漿量を $110 \mathrm{~m} l$ として, 血中 UK 濃度が 11.1 単位と予測されたが，実 験結果は何ら線溶活性を測定することができな かった. UK 40,000単位を 11.5 分で投与した場 合 (毎分投与量 3,478 単位), 血中 UK 濃度が 50.2 単位と予測されたが，実験結果では，線溶 活性が 8 分目で出現し，投与中には UK 濃度 のプラトー值はみられなかった。これらの結果 を antiplasmin の役割と共に論じた.

\section{文献}

1) Matsuo, O., et al.: Assessment of the thrombolytic effect of low urokinase concentration Acta Haematol Jap., 39;298-305,1976.

2) Goldstein, A., et al.: The time course of drug action. In "Principles of drug action”. Harper \& Row, Publishers, New York, p. 280 342, 1968.

3) Woodard, W.T., et al. : The fate of infused urokinase. Surg., 68; 692 697, 1970.

4) Som, P., et al. : Radiolabeled streptokinase and urokinase and their comparative biodistribution. Thromb. Res., 6; 247 253, 1975.

5) Tajima, I., et al.: Metabolic fate of urokinase. Chem. Pharm. Bull., 22; 727 735,1974

\section{$<$ ABSTRACT $>$}

Relation between UK concentration in plasma and administered dosage of UK

by

Osamu MATSUO, Hisashi MIHARA, Yoshikazu ROKUSHIMA*

from

Department of Physiolosy, Miyazaki Medical College and *Department of Physiology, Kobe University School of Medicine. 
Using the plateau principle, the UK concentration in the plasma after UK administration was estimated, the plateau value being $\frac{\mathrm{A}}{\mathrm{k} \cdot \mathrm{V}}$ unit $/ \mathrm{ml}$, where $A$ is the infusion speed of UK (unit/min); $\underline{\mathrm{k}}$, the inactivation rate constant of UK activity $\left(\mathrm{min}^{-1}\right)$; and $\mathrm{V}$, the plasma volume $(\mathrm{ml})$. Therefore, the plasma UK concentration depends mainly upon the infusion speed of UK because the plasma volume and the inactivation rate constant of UK activity are considered more or less constant. The plasma UK concentration after UK administration can, thus, be estimated, and such estimation of plasma UK concentration is very helpful for the assessment of the thrombolytic effect of UK since plasma UK concentration is one of the important factors in the thrombolysis. Although application of the plateau principle in one compartment necessarily involves an oversimplification of the true physiological distribution and breakdown kinetics, it allows reasonably an estimate of the plasma UK concentration.

In order to evaluate $\mathrm{k}$, the inactivation rate constant of UK in the circulatory blood which involves the inactivation process by antiplasmin and excretion by metabolic process, 20,000 units UK were injected into a rabbit at one shot, and then the plasma fibrinolytic activity was measured. Based on the linear relationship of the decay in plasma fibrinolytic activity on the semilogarithmic paper, $\mathrm{k}$ was calculated to be about $0.7\left(\mathrm{~min}^{-1}\right)$. These allowed to draw the time course of plasma UK concentration after UK infusion, which revealed that plasma UK concentration reaches the plateau value about $6 \mathrm{~min}$ after the commencement of UK infusion.

Then, the estimated plasma UK concentration was examined comparing with the one obtained in the experimental study. In the case of 30,000 units UK administration for 35 $\mathrm{min}$ in a rabbit (the infusion speed, 857 unit/ min), the plasma UK concentration was estimated to 11.1 unit $/ \mathrm{ml}$. However, any fibrinolytic activity in plasma and euglobulin fraction was never observed during the administration. When 40,000 units UK was administered for $11.5 \mathrm{~min}$ in a rabbit (the infusion speed, 3,457 unit $/ \mathrm{ml}$ ), an estimated plasma UK concentration was $50.2 \mathrm{unit} / \mathrm{ml}$. However, the fibrinolytic activity was appeared eight min after starting the UK infusion, then increasing rapidly, but the plateau value was not observed during the UK administration. These results were different from the theoretically estimated results, and suggest that plasma UK concentration is much less than the estimated value. However, the estimation of plasma UK concentration would be one of the useful methods which can explain reasonably the effect of urokinase on the in vivo thrombolysis. The inactivation process of UK in the circulatory blood was discussed with the biological action of antiplasmin.

\section{$\langle$ DISCUSSION $>$}

有賀豊彦 (日本大学医学部第二生理学)

家兔に対して $30,000 \mathrm{u}$. UK を投与して, UK 活 性を認めなかったものが，40,000u. UK を投与し て線溶活性が初めて認められるというととは，A という factor に, Anti-plsの反応性（例えば, 時間的な function を考慮した inhibitory act. との）を考えなくてはならないのではならない 加。

\section{松尾 理 (宮崎医科大学生理学)}

重要なのは，投与量そのものではなく，投与速 度，すなわちUK の毎分投与量 A の大小である. 例えば，毎分投与量が小さいと，投与量がいくら 大きくても，血中線溶活性の発現はみられない. 一方, 毎分投与量が充分大きいと, 線溶活性の発 現がみられる。これらのことから，線溶活性の発 現には，threshold があって，それを越えるとは じめて線溶活性の発現がみられる。この threshold は大体3,000単位/分である.乙れらは, two compartment model を使えば，かなりうまく説 明できそうである。

\section{椙江 勇 (愛知医科大学生理学)}

1）家兔にUK を投与した UK の活性カーブ と理論的なカーブとの主な差は活性出現までの時 間的なおくれが主であり立ち上ちカーブの形は急 勾配であり理論值とあまり差のないてとは排出速 
度等の問題より anti-pl もしくは anti-UK など の Inhibitorによる消費絶対レベルが主な問題と みられます。

松尾 1） time lag という考え方濽成である. その time lag を説明するために, 先ほどの質問 に対する答の中で, threshold という言葉を使用 したが, このメカニズムは, two-compartment で説明可能である.

2）線溶活性出現後の立上りのカーブは, 予測 通りにならない。

田中健蔵 (九州大学医学部)

UK の血中からの除去はどのような機序を拈考 えでしょうか. 網内系による貪食と腎からの排泄 があると思いますが.
次に私どもの実験では，家鬼を用いると，自家 血栓は, in vivo で, UK 投与により溶解は促進 されませんが, 螢光抗体法では UK は血栓内に 認められます. すなわち UK は投与後血管内に あるがその活性があまり発現しないのではないか と考えられます. antiplasmin 活性の高い家兔の みでなく, 他の動物を用いて検討されれば, 先生 の理論がより明らかに証明されるのではないかと 思います。

松尾 文献的に Isotope を用いた成績で labeled UKが腎および肝に集積している成績から，てれ らの臟器に trap されて除去されると推定してい ます．種を変えた実験むやってみたいと思います． 